\title{
The Protection of Historical Artifacts in Ottoman Empire: The Permanent Council for the Protection of Ancient Artifacts ${ }^{i}$
}

\author{
Sefa Yildirim*, Fatih Öztop \\ Department of History, Faculty of Science and Letters, Ağrı İbrahim Çeçen University, Turkey
}

Copyright $\odot 2019$ by authors, all rights reserved. Authors agree that this article remains permanently open access under the terms of the Creative Commons Attribution License 4.0 International License

\begin{abstract}
The historical artifacts that reveal the social, political, aesthetic, moral, architectural, etc. stages, through which the human beings have been; which transfer and reveal information from past to present and future; which have an artistic, historical or archaeological importance are very important physical elements that the present-day civilized societies protect or must protect as cultural values. Such works both strengthen the ties to the past due to the transfer of cultural heritage to existing and future generations and plays a very important role in the writing of the past through the data provided to the researchers. The protection of the historical artifacts was under sharia laws until 1858 in Ottoman Empire, since then, some regulations were done about this issue, in the end, The Permanent Council for the Protection of Ancient Artifacts was established on 21 May 1917 and they reported their one-year activities. In the report prepared by the Council, the first point that draws attention is the fact that they divide Istanbul into two parts as old and new. While the old Istanbul draws attention with the artifacts of Rome and Byzantium and is the region to which the archaeologists give great importance; the new Istanbul is the "eximious" Istanbul that started after the conquest, formed with the examples of beautiful lore artifacts and examples of the civilization. Another important detail of the report is the emphasis on the fact that the Ottoman Turks left the artifacts which demonstrate that "the lore of the Ottoman Turks and their ability in civilization cannot be rejected and denied". When both the Turkish presence in Istanbul and the similar proclamations of the right to life of the Turks here are brought together, the same emphasis is seen that as well as the protection of historical artifacts, the Permanent Council for the Protection of Ancient Artifacts tried to prove its reasonable and legal grounds of its presence in the Ottoman territories, particularly in İstanbul. Within the scope of this study, the point of view of the Ottoman State towards the historical artifacts before the establishment of the Permanent Council for the Protection of Ancient and the
\end{abstract}

establishment, functioning, duties and activities of the before-said council are tried to be explained.

Keywords Historical Artifacts, Protection of Historical Artifacts, Council

\section{Introduction}

The first initiative for the protection of the historical artifacts in the Ottoman Empire can be considered as the beginning of the storage of two collections of old weapons and artifacts since 1846 in the Hagia Irene Church (Sertoğlu \& Açık, 2013, p.160). This museum which was prepared by the initiatives of Tophane-i Amire Müssiri (the Marshal of the Imperial Arsenal) Fethi Ahmed Pasha, could only be visited with special permission as it is being closed to the visitors (Kuruloğlu, 2010, p. 48). Within the westernization works that accelerated after the Tanzimat period, the importance given by the European states to the historical artifacts since the Renaissance period gradually began to be understood in the Ottoman Empire as well; however, the works on the preservation of the historical artifacts also confronted similar difficulties, as western-style institutionalization works had confronted. The primary problem was that in this area of activity there was no qualified and experienced manager. Furthermore, the absence of a law and regulation written in these years to preserve historical artifacts deprived a legal ground for the aspects such as the definition of historical artifacts, which objects were historical artifacts, where and how they would be preserved.

The historical artifacts called "asar-i atika (antiquities)" in the Ottoman Empire was subject to the principles of fiqh (Islamic Law) until the regulation in 1869 and the fiqh mentioned about the historical artifacts as movable goods, of which "the owners and proprietors are unknown", the right of property of the real estate and the 
goods, of which the "proprietor is known" was complex (Mumcu, 1969, p.66). Because "possession" and "property" were one of the most controversial topics of fiqh (Topal, 2013, p.417), the immovable historical artifacts could be property of the foundations, private persons or the state. If the artifact belonged to the state or private persons, in this case, as the owner could have all kinds of right of disposition, he could use the artifacts as he wished, destroyed it or reformed it according to his own use (Mumcu, 1969, p.66). According to Mumcu, the historical artifacts under the administration of foundations, especially the mosques, had much better conditions than others (Mumcu, 1969, p.66); however it is difficult to reach the same judgment for other artifacts. Because a historical artifact consciousness had not been acquired in the Ottoman Empire, sometimes old coins were used in the minting of new coins (Şimşek \& Dinç, 2009, p. 105) or the historical artifacts were not treated well and (Şahin, 2007, pp. 104-109) they were destructed consciously or unconsciously. Pragmatically this was developed out because the value of the historical artifacts was not known/ understood; the objects such as coins or metal sculptures were considered more valuable as mines. Thus, there was no drawback in melting of a golden coin, considering that it would work more as gold, not as a coin.

The first provision related to historical artifacts took place with the $133^{\text {rd }}$ article of the Ottoman Penal Code dated 1858, which stated that "Whoever destroys and ruins or breaks down some part of religious charities and ornamented buildings of the cities and aforementioned artifacts will be sentenced of imprisonment from a month to a year and fined for one Mecidiye gold to ten Mecidiye gold after having been compensated the loss” (PMOA, İ.DUIT 78/31); however, there was not any provision concerning the discovery, search, excavation and preservation of the historical artifacts. Since there is no description of historical artifacts in this article, there is a protection provided more for the immovable artifacts and in an unclear manner, mostly monumental a more than chattel goods (Mumcu, 1969, p. 68). It also has a structure that can change according to interpretation (Çal, 1997, p.391).

Between 1868 and $1871^{\text {ii }}$, Irish Edward Goold, one of the teachers of the Galatasaray High School, was appointed to the "store-museum" in Hagia Irene Church (Mumcu, 1969, p.66). Although the Ottoman Empire wanted to take a western step towards preserving and displaying historical artifacts through this appointment, which took place before the 1869 regulation, a while after this appointment, the first Regulation which was directly about the historical artifacts, 13 February 1869 would be published in the journal Takvim-i Vakayi.

This regulation, which consists of 7 articles with introduciton, did not provide any definition for historical artifacts but it stated that the excavations from now on were subject to the permission of the Ministry of
Education. Despite the fact that the second article forbade the historical artifacts to take abroad, the antique coins were excluded in the fourth article. It was stated that only excavation licenses would be granted for the artifacts found underground and that no excavation license would be given for the artifacts that were visible regarding unearthing the historical artifacts (Takvim-i Vakayi, 1 February 1284). Before putting this regulation into force, the historical artifacts found could be taken by the person who conducted the excavation "hafir (digger)"; however, if there were two artifacts found, one of them would be left to the Ottoman Empire. With the regulation of 1869, it was declared that this practice should be abandoned because of the inconveniences such as the rare discovery of this kind of artifacts and the possibility of the fact that the hafir could hide the double artifacts which were found and a perfect regulation should be prepared about the museums to be established (Takvim-i Vakayi, 1 Februrary 1284).

The Ottoman Empire, which wanted to carry out the activities in a more systematic way with this regulation, aimed to place the system of westerners in the Ottoman museums by appointing firstly Austrian Terenzio after Goold and then Philip Anton Dethier as the director of the museum. Because the problem of lack of qualified and sufficient personnel during the Tanzimat period (1839-1876; It is the name of the modernization and westernization period that started with the Gulhane Hatt-i Sharif in 1839 in the Ottoman Empire) was tried to be solved by bringing foreign experts. Nevertheless, the fact that there is no museum building in modern sense has brought an existing weakness to the Ottoman Empire in terms of the preservation of historical artifacts. Because historical artifacts and weapons of the Ottoman army were kept in the same stores. Naturally, this situation attracted the reaction of the Seraskerat (supreme commander) authority, and demanded the Incili pavilion to be converted into a museum with an aim to solve the problem lack of place that emerges as new rifles arrive and so that the visitors could see the weapons that the Ottoman Empire had under the protection while they visited the historical artifacts. In response to this demand, the Babiali (Government) made a decision to arrange the Cinili Pavilion as a museum (PMOA, A.MKT.MHM 471/11).

Since the necessity of preparing a more systematic and comprehensive new system was already known due to the deficiency of the regulation dated 1869, after the construction of a new building, the regulation named "The Regulation on Historical Artifacts and Official Report about Protection in 1874 was published. The first definition for the historical artifacts was made in the first article stating, the objects made with all kinds of arts dated from the ancient times are among the historical artifacts" (Düstur, I. Tertip, V. 3, p.426). In this definition, "masnu " is used to mean the artifact that are made by humans, that is, artifacts made through an art, and with 
"ezmine-i kadime", that is, dated from the ancient times formed a general timeline. Thus, since there is no clear definition of the word "ancient", the introduction has been made open to the interpretation. These two points should be regarded as normal within the conditions of the period, even though they may be criticized in comparison with modern "historical artifacts". Because today, although many objects, from human and animal remains to fossilized agricultural products, are important elements especially in the art of archaeology, it is possible to define only the artifacts made by humans as historical artifacts in the 19th century.

According to the second article of this regulation, the historical artifacts are divided into two categories in a strange way (Mumcu, 1969, p.70). The first is the coin; the second is the movable and immovable goods. In addition, it is stated that unexplored historical artifacts are the property of the state and that the artifacts found in the excavations with permission are to be divided between the founder of the artifact, the land owner and the state (Düstur, I. Tertip, V 3, p.426). Thus, the article stating that one of the two artifacts which had been applied before would be given to the state is annulled. On the other hand, it is an important step for the protection of immovable artifacts in terms of "demonstrating the first time that it has been accepted by the state" (Mumcu, 1969, p.71).

In the second part of the Regulation, there are the provisions regarding the "exploring and excavation" of historical artifacts, and the provisions on obtaining licenses and uncovering the historical artifacts (Düstur, I. Tertip, V 3, pp. 426-428), in the third part; the provisions regarding the fact that it is necessary to inform the local authority within ten days if any artifact is found and how the historical artifacts found would be shared (Düstur, I.Tertip, V 3, p.429). In the fourth part regarding the taking the historical artifact abroad, bringing the historical artifacts in the country, purchase and the sale of the historical artifacts, it is stated that the customs duty will not be demanded for the historical artifacts to be brought from abroad but the artifacts to be taken abroad will be subject to the customs duty and if the artifacts that are tried to be smuggled through the customs are captured, they will be garnisheed by the state (Düstur, I.Tertip, V 3, p.431). Thus, the law stipulates that there is no inconvenience in the export of historical artifacts abroad, provided that the customs duty is paid. Although this provision aimed at preventing the smuggling of historical artifacts, at least it permitted the historical artifacts to be taken abroad under state control.

In the last part of the regulation of 1874, it is mentioned that the punishment to be given to those who destroy historical artifacts will be applied as it is indicated in the penal code. $5 \%$ tax will be collected from historical artifacts sold at auction and together with monies taken or collected in this way from the historical artifacts, the income acquired from the fees received from the seized artifacts will be given to the museum box (Düstur, I.Tertip, $\mathrm{V} \mathrm{3,} \mathrm{p.431).} \mathrm{In} \mathrm{this} \mathrm{way,} \mathrm{it} \mathrm{was} \mathrm{decided} \mathrm{to} \mathrm{transfer} \mathrm{the}$ income to the museums established and to be established by means of the museum box.

After the death of Dethier, Osman Hamdi Bey was appointed by the Sultan Abdulhamid II, became the person who initiated the museums in the modern sense in Turkey by "taking Istanbul Archeology Museum from its modest situation and making it one of the world's most important museums" (Mumcu, 1969, p. 72). One of the first actions of Osman Hamdi Bey was to prepare a new regulation for the preservation of historical artifacts. This regulation, which was announced on 20 February 1884, annulled the previous regulations.

Although the regulation dated 1884 consisted of 5 parts and 37 articles, it was written as the third part from the 15th article without writing the titles of the first and second parts within the Düstur I. Tertip Zeyl 4. In the first article, the description of the historical artifact was made and it is stated that everything the folks who lived in the past left is historical artifacts by indicating "all the artifacts that the ancient folks abandoned" and later on, the precedents were tried to be mentioned one by one by giving examples to it. The third article emphasized that all the artifacts which had been unearthed/discovered before and to be unearthed from then on belonged to the Ottoman Empire. One of the important emphasizes in this regulation is the site area procedure mentioned in the fifth article. In addition to opening lime-kiln within 4 kilometers and permitting to any construction nearby the historical artifacts, it is strictly forbidden that the landowner of the area where a historical monument is located are not allowed to carry out agricultural production or making swimming pools, troughs and fountains by using the historical artifacts here. Another prohibition is stated in Article 8 of the regulation and it declares that it is strictly forbidden to take the historical artifacts unearthed within the Ottoman territories abroad. The historical artifacts to be unearthed with an official license belong entirely to the state museum, and the excavators can only take pictures or patterns (Art.12). If a person coincidentally finds a historical artifact during a construction, half of the artifacts will be left to that landowner, and will be able to purchase this monument in-kind and cash (Art. 14). Although this article contradicts the fact that all of the historical artifacts belong to the state, the condition of paying the price in the name of not infringing the state financially was introduced.

Although it was stated in the article 8 in this regulation, it is prohibited to take all kinds of historical artifacts abroad. However, if an artifact has an equivalency in the Ottoman museums in terms of genre and value, it could be taken abroad with a license from the Ministry of Education. Secondly, an artifact brought from abroad to the Ottoman territories could also be taken abroad. 
The fifth and final part of the Regulation was completed by saying that those who destroyed the historical artifacts, the ones who did not know the historical artifacts they had found by chance, the penalties to be given to those who moved a historical monument excavated in the Ottoman territories to another place and declared in the thirty-seventh article "the Ministry of Education is responsible for the implementation of this Regulation” (Düstur, I. Tertip Zeyl 4, 1302, pp. 89-97).

Although this regulation had a clearer definition for the historical artifacts than the previous ones, it had an open-end structure with the concept of "ancient folks". Because the ancient folks refer to the folks who lived in the past but did not continue to exist on that day? In other respects, what is the role of the artifacts constructed in the founding years of the Ottoman Empire in this definition? The regulation, which fails to give clear answers to these questions, was used until 1973 (Mumcu, 1969, p. 72) with minor changes (without touching the outlines) (Çal, 1997, p. 393). The amendments made to this regulation were made with the regulation dated 23 April 1906.

In the first part of the regulation (1906) with 35 articles consisting of different provisions of 6 parts and 4 articles, the systematics of the direction of the imperial museum, which covers the historical artifacts administration, and its connection with other institutions are explained. In the second part, it is emphasized that all the historical artifacts of which the existence is known and which will be discovered in the future are the property of the Ottoman State (Art.4) and then the historical artifacts were defined. The notable point in this definition is that antique artifacts belonging to "Islamic Fine Arts" with the distinction between movable and immovable goods are included in this definition. In addition, in the fifth article, the artifacts which contain many historical identities from the museums to the basilicas, from the hippodromes to the waterways, from the manuscripts to the coins and even to the houses were listed; in the sixth article, natural formations in any archaic walls and artifacts remnants of the monument such as "stone, glass and tree fractures" were taken into the statue of the historical artifacts. Although the regulation was popularized by so detailed examples, the "old" concept was nevertheless new for the Ottoman Empire (Çal, 1997, p.393), and the effort they had made to establish its systematic was praiseworthy.

The next parts of the Regulation contain provisions regarding the exploration and excavation requirements, licenses and fees, and the historical artifacts that may be brought from abroad. While the artifacts taken from abroad are exempted from the customs duty, the artifacts to be taken abroad are subject to the approval of the Ministry of Education and the condition that a peer should be in the Ottoman museums (Düstur, I.Tertip, V 8, 1943, pp. 506-515). It was determined that "for the first time the Directorate General of the Museums would carry out all the works regarding all the historical artifacts". (Çal, 1997, p.393).

A new Bill was drafted under the name of Ancient Artifacts Draft Bill (Asar-i Atika Kanunu Layihası ${ }^{\text {iii }}$ ) (1921) in the time of Osman Hamdi Bey's brother Halil Erdem Bey who was appointed to the same post after his brother and in the time when Istanbul was occupied by the Allies. The first part of this draft bill, which consists of 43 articles, contains provisions on the types and implementation of historical artifacts. After writing a time interval in the name of historical artifacts with the expression "artifacts belonging to late Gregorian seventeenth century and hijiri eleventh century " in the first article, many historical examples have been written from dervish lodges to monasteries, hippodromes to tombstones. Also, the artifacts belonging to education, science and literature were also considered as the historical artifacts (Asar-i Atika Kanunu Layihası, 1336, p.2). It is stated in the seventh article of this law that all the artifacts are regarded as property of the government and it is stated that the artifacts such as the castle or fortress can be destroyed after being photographed as a necessity (forming the danger) (Asar-i Atika Kanunu Layihas1, 1336, p.4). It was also decided that, in the event of returning to the former, a part of what hafir found would be left to him, but if the artifacts were fixed to the floor, a suitable accommodation would be given to him instead of division (with alliance). However, it was stated that it was possible to bring out the share which had been left to his own property, even though the exportation of historical artifacts were not possible (Art. 34) (Asar-i Atika Kanunu Layihası, 1336, p. 12).

\section{Foundation of the Permanent Council for the Protection of Ancient Artifacts}

Although the Ottoman Empire tried to find a solution by introducing laws regarding the protection of historical artifacts, there were always some problems because the citizen and the administrators were not conscious enough on this issue. The pieces that belong to historical artifacts were sometimes used or tried to be used in the construction of cinema, sometimes used in the construction of barracks and those who found historical artifacts did not inform police and gendarmerie forces in time. Even if they were informed, it is understood that the security forces have exhibited a insusceptible attitude because they should not consider the preservation of historical artifacts as their real duty. In order to solve this issue, in the Ministry of Education, especially for on police and gendarmerie lectures had been organized and firstly awareness had been tried to be raised (PMOA, DH.IUUM.EK 33/36).

The destruction created by the World War I, in the years when the Ottoman Empire was in a struggle for a 
survival, measures for the protection of the "historical artifacts and national artifacts" were tried to be taken (PMOA, DH.İUM.EK 33/36). The first place to start this work in this regard naturally was Istanbul. In order to oversee the preservation of the historical artifacts in Istanbul, to apply their votes for the restoration of the historical artifacts, including the Old Imperial Castle and to take measures to save the historical artifacts and not to destroy them, or to determine the necessities of demolishing them, it was decided to construct a council with the Halil Bey ${ }^{\text {iv }}$, Head Manager of the Museum; İsmet Bey $^{\mathrm{v}}$, Deputy of Istanbul; Dr. Nazim Bey ${ }^{\mathrm{vi}}$, Director of Construction and Repair of Foundations; Architect Kemaleddin Bey ${ }^{\text {vii }}$, Director of Ministry of Internal Affairs Director of State Buildings; Efdaleddin Bey ${ }^{\text {viii }}$, Member of the Council of History; Mehmet Ziya Bey ${ }^{\text {ix }}$, Member of the Delegation of Education Copyright and Translation and Architecture Asım ${ }^{\mathrm{x}}$, Architectural Branch Manager of the Municipality Technical Delegation; Celal Esad Bey ${ }^{x i}$, Director of the Kadiköy Office (May 16, 1917) (PMOA, MV 208/23, BEO 4470/335244). It was strictly forbidden to carry out repairs and demolitions on historical artifacts without the consent and approval of The Permanent Council for the Protection of Ancient Artifacts (PMOA, DH.UMVM 66/67). The most accentuated word during the establishment phase of this commission was the preservation of the "national artifacts" (PMOA, DH.UMVM 66/67), which is an especially underlined statement of the Council's work.

This council established by the personal efforts of Halil Bey (Eyice, 1995, p.19) was likely to be made up of competent, talented and diligent people through Halil Bey's suggestion. When we look at the founding members of the Permanent Council for the Protection of Ancient Artifacts, it is seen that there were people who had marked in era, made important things for Ottoman Empire as well as the Republic of Turkey and achieved extremely successful business in the fields of museology, art and architecture. Even the presence of only these chosen members is an indication of the seriousness and sincerity of the work of this council in the establishment phase and in the preservation of historical artifacts.

\section{Activities and Report of the Permanent Council for the Protection of Ancient Artifacts}

On 31 May 1918, the law on the formation and duties of the Permanent Council for the Protection of Ancient Artifacts was sent to the Deputies Assembly for approval. The content of this Draft bill consisting of 6 items can be summarized as follows:

Under the Presidency of the Ministry of Education, a council composed of specialists was formed, under the name of "The Permanent Council for the Protection of
Ancient Artifacts". This council has an additional budget on the budget of the Ministry of Education ${ }^{x i i}$. The Council contains the historical and monumental details of the real estates and details regarding the historical buildings and historical buildings keep a registry book and publish works containing information about them. In the case of repairs, alterations, transfers or demolitions of the historical buildings mentioned in the second article, it is compulsory to apply in written form and to act according to their decision. Otherwise, penal procedure shall be initiated in accordance with the Article 133 of the criminal law. The Council shall notify its decision on the applications made to them within six months at the latest; if a decision is not notified within this period, it is accepted that the requested operation has been approved. If any damage occurs in the event of a decision taken by the Council according to the third article, the government will issue the damage in this case. An application must be filed within five years at the latest about the caused damage; otherwise the right to claim for damages will not be any longer valid (PMOA, MV 212/115).

The legislative process of the draft bill had gone on for quite a long time, although it was not known whether or not a separate regulation including the structure of the duty and organization of The Permanent Council for the Protection of Ancient Artifacts was established. In a letter sent to the Presidency of the Deputy Assembly on 17 February 1920, to Grand Vizier Writing Office it was reported that "aforementioned law draft should go into force erewhile” (PMOA, BEO 4616/346176).

As the legislative process of the draft bill had not yet been completed, The Permanent Council for the Protection of Ancient Artifacts had started its activities rapidly and published a report containing one year's activities (Muhafaza-1 Asar-1 Atika Encümen-i Daimisi Bir Senelik Mesaisine Dair Rapor, 1336,).

The council mentioned Istanbul in the report firstly. By expressing their participation in the opinions of those who divided Istanbul into two, the council also divides Istanbul in two parts as Old and New Istanbul. Because of the old Istanbul contained artifacts and fine arts from Roman and Byzantine periods. Historians and archaeologists have been examining these artifacts with great care. Old Istanbul was a research ground that one cannot remain indifferent to its story, and its buried secrets. New Istanbul started after the conquest of Turks. The New Istanbul is a distinguished example of the Ottoman Empire's civilization with its beautiful works of wisdom. "At the end of the eight hundred years of Hijrah, every page of this magnificent manuscript about the magnitude of their lore and the capabilities of the civilization will not be rejected or denied by the Ottoman Turks.” (Muhafaza-1 Asar-1 Atika Encümen-i Daimisi Bir Senelik Mesaisine Dair Rapor, 1336, p.3).

In the aftermath of the construction of Istanbul, the Council wrote a report on the following expressions in the 
form of a self-criticism: "all artifacts of Old Istanbul, while all details of some cases were known and recorded under the jurisprudence. We have neglected the determination of the stages that will serve to make our social life an example in the sense of pride and proudness" (Muhafaza-1 Asar-1 Atika Encümen-i Daimisi Bir Senelik Mesaisine Dair Rapor ,1336, p.3).

After the self-criticism of the historiographical writing, the following expressions from the sensitivity of the Ottoman State to the preservation of the Roman/Byzantine artifacts were mentioned: Evidenced by the views of neutral professors like Charles Diehl, after 57 years of destruction caused by the Latin invasion, one per thousand from the artifacts that were the products of lore and civilization for centuries left to Ottoman period, while in the Ottoman era, four hundred and sixty-odd years, the artifacts still exist and enduring. Thus, the council stated that "we need to teach the world that our ancestors not come to these places by shaking their swords alone but to serve in the fields of the promotion of the cities and the improvement of their lives". In the same report it was also stated that "Our national entity and racial commitment in this land therefore our right to life and stability can be proved and confirmed by the tremendous and magnificent artifacts that are the remnants of our ancestors.” They are trying to base their associations and possessions on this account only on artifacts that can survive, and pretension about them. As of them, they also focused that "we cannot terminate the artifacts of predecessors by destroying and demolishing”. (Muhafaza-1 Asar-1 Atika Encümen-i Daimisi Bir Senelik Mesaisine Dair Rapor , 1336, pp. 4-5).

As it can be seen through the expressions clearly, in the years of World War I, especially on the defeats against the British, both defending the "right of life" on Anatolia and Istanbul and proving that the Ottoman Turks are people who contributed and preserved the civilization were other purposes of Council. It can be claimed from the following quotation that they are aware of what kind of role the council plays politically from the expressions that "in this respect, since we have the wealth and the strength to prove the degree of our existence in every county of Anatolia, it is essential that we preserve even the most unimportant things in our perspective." Because, in the direction of Megalo Idea which is about the Greek policies on Istanbul and the psychological pressure created by the claims and due to the pressures towards the Ottoman State in the world public opinion, The Permanent Council for the Protection of Ancient Artifacts worked in this direction in order to weaken the Greek policies.

The council stating the demolitions of many artifacts because of different reasons that proved the presence of the Ottomans in Istanbul made the following statement: "There are hundreds of our mosques, masjids, tombs, lodges, historical cemeteries (...) only in Aksaray and the burned places nearby (...) the graves of many mujahids who reached the martyrdom in the conquest of this place, scholars and brilliant people" were fractured. After expressing that they can prove the existence and the history of the Ottoman Empire only with these artifacts, "they should not be permitted to their destruction in any way whatsoever (...) because they are both important in their own history and in the history of the country". (Muhafaza-1 Asar-1 Atika Encümen-i Daimisi Bir Senelik Mesaisine Dair Rapor, 1336, p.5)

According to the Council's report, neither Barbara Palas nor any building built in strange style was the goal of those who visit Istanbul; The only sign that shows Istanbul's power and value was the Eastern style and national artifacts that if we ignored this situation and engage this city only with a European (Greek) city pattern through Roman/Byzantine artifacts, "we will think of this situation a great rape against our national existence on this point" (Muhafaza-1 Asar-1 Atika Encümen-i Daimisi Bir Senelik Mesaisine Dair Rapor , 1336, p. 5)

Until this point, the council gave information about the basic physical structure / history of Istanbul and provided reasons for the political contributions of the Ottoman Empire to the civilization, and tried to give its activities in the following lines.

In order to protect the artifacts and national structures that the ancestors built up at the most remote corners, introduce beautiful treasures, protect them from negligence, from rape to which they will be subjected and not to allow such unfavorable things, the council founded on 31 May 1918, Friday, detected, photographed and pictured "the national and antique artifacts where Istanbul included or separated since 23 May 1918" such richest neighborhoods and districts of Istanbul at the point of national artifacts as Ayvansaray, Sultan Selim, Fatih, Saray-1 Guzel, Cerrah Pasha, Aksaray and the surrounding artifacts.

According to the inspection committee, the places mentioned above, which are the most exceptional districts and neighborhoods of Istanbul, are among the biggest centers; as the artifacts and monuments, which were built by the ancestors who were connected to their country and nations with a true and religious tie, were exposed to attacks and danger by means of fire, a secondary commission spent their efforts to these places. Thus, a separate file was created for each artifacts, and artifacts related to pictures, photographs, sketches, plans, writings in the inscriptions, and the identification of these inscriptions were made and their locations were marked on the map (Muhafaza-1 Asar-1 Atika Encümen-i Daimisi Bir Senelik Mesaisine Dair Rapor, 1336, p. 6)

In addition to the paintings that would constitute a perfect collection, if the conditions are more favorable, a collection would also be made about the gravestones that completely articulate the subtleties of art and national spirit such as mosques, fountains and tombs which constituted the magnificence of the Ottoman civilization, 
(Muhafaza-1 Asar-1 Atika Encümen-i Daimisi Bir Senelik Mesaisine Dair Rapor, 1336, p 7).

Another important activity of the Council was to record, photograph or depict historical artifacts in various places of Istanbul, to locate them on the maps and record them in order to ensure that they were not destroyed or demolished. Given that they carried out these studies within a year so there might be a perception that they did very little; however, when the physical conditions and history of Istanbul, and the existence of artifacts of historical importance on almost every side, the activities performed by the council for one year were at least an activity that can lead to enough working expenses even if only to register.

After a year's activity, it promises to act in order to make a decision about them regarding the preservation, recording or demands of the historical artifacts in the Ottoman Empire by sending delegations to other provinces, especially Bursa, by doing a similar activity for the artifacts (Muhafaza-1 Asar-1 Atika Encümen-i Daimisi Bir Senelik Mesaisine Dair Rapor, 1336, p 7). Finally, the artifacts, which had not been examined and determined "properly" by no one in nowhere, belonging to Sokullu Mehmed Pasha, were identified and their sketches and pictures were taken.

After the statements on their activities, the council completed the report by thanking the Ministry of Foundations, the Ottoman intellectuals, the Ottoman publics and the city (Muhafaza-1 Asar-1 Atika Encümen-i Daimisi Bir Senelik Mesaisine Dair Rapor, 1336, p.7).

In 1924, during the time when Vasif Bey worked as the Deputy of the Ministry of Education, , an instruction consisting of 17 articles was prepared and after that the council was operating in accordance with this instruction. Initially the number of the members were eight, but the number increased to 13 with the addition of museum directors and a clerk in Istanbul ${ }^{\text {xiii }}$.

The membership in the Council as the Museum architect remained unoccupied in 1939 (Arseven, 1950, pp. 533-534). However, in the activity report of 1939, Kemal Altan's name was pronounced as the Museum's Architect (Eski Eserleri Koruma Encümeni 1939 Yılı Mesaî Raporu, 1940).

In 1939, the council that published a working report explained its establishment and activity aims: "In terms of national culture, as witnesses of the artifacts remaining from past to future and proceeded to present, the council should protect everything related to these old artifacts, reveal their essences, know the unknown sides, and produce the information files which were so tremendous and tough processes to be completed" (Eski Eserleri Koruma Encümeni 1939 Yılı Mesaî Raporu, 1940) p. 7)

\section{Conclusions}

The Ottoman Empire, which first took measures for the preservation of historical artifacts through the Penal Code of 1858 for the first time aimed to create an awareness and protection for historical artifacts, beginning from 1869. Until the establishment of The Permanent Council for the Protection of Ancient Artifacts, the works were carried out through the Directorate of Imperial Museum. Along with the "existence" anxiety that lived towards the end of World War I, actions were taken in order to protect the Turkish-Islamic artifacts of the Ottoman civilization, especially in Istanbul. The Ottoman administration, which had to force itself to produce "counter-thesis" against the plans to occupy Istanbul and Anatolia by Allies during the World War 1 and to shake up the legitimate foundations of Turkish dominance there, established The Permanent Council for the Protection of Ancient Artifacts provided that the preservation, classification, maps and plans of the works which the Ottoman Empire has brought to the world civilization and publications about them.

The Council of which the selected experienced experts who will actually work in the establishment phase, worked on the determination of the places of many works, especially Turkish-Islamic artifacts located in Istanbul, and the preparation of the marking, sketching and planning of the artifacts on the map. Looking at Halil, Asım, Efdaleddin and Celal Esad Bey's next works and the artifacts they had produced, it is seen that they were very sensitive to the duty within the council or in the individual sense.

In spite of the foreign occupations and regime changes after the World War I, The Permanent Council for the Protection of Ancient Artifacts continued its duty in the name of Preservation of Ancient Works and the Council has undoubtedly played a very important role in the protection and revelation of historical artifacts both for state and the public awareness.

\section{REFERENCES}

[1] Sadâret Mektubî Kalemi Mühimme Kalemi (Odası) Evrakı: A.MKT.MHM 471/11.

[2] Bâb-1 Âlî Evrak Odası: BEO 4155/311577; 4321/324055; 4470/335244; 4479/335863; 4616/346176.

[3] Dahiliye Nezareti İdare-i Umumiye Evrakı DH.I.UM 12-2/4-39; 12-2/4-6;

[4] Dahiliye Nezareti İdare-i Umumiye Evrakı Ekleri: DH.IUM.EK 33/36. 
[5] Dahiliye Nezareti Şifre Evrakı: DH.ȘFR 61/274.

[6] Dahiliye Nezareti Umur-1 Mahalliye ve Vilayet Müdürlüğü Evrak1: DH.UMVM 139/11; 66/67.

[7] İrade Taltifat Evrakı: İ..TAL 492/6.

[8] Dosya Usulü İrade Tasnifi: İ.DUİT 13/68; 68/120; 72/35; 78/31; 90/14.

[9] İrade Evkaf Evrak1: İ.EV 45/32.

[10] Maarif Nezareti Mektubi Kalemi Evrak1: MF.MKT 1091/41; $1109 / 14$

[11] Meclis-i Vükela Mazbataları: MV 208/23; 212/115.

[12] Bakanlıklar Arası Tayin Daire Başkanlığı: 30-11-1-0/4-12 -14 .

[13] Asar-ı Atika Kanun Layihası. (1336). İstanbul: Matbaa-i Amire.

[14] Düstur, I. Tertip Zeyl 4, (1302). Dersaadet: Matbaa-i Osmaniye.

[15] Düstur, I.Tertip, V. 8, (1943). Ankara: Başvekâlet Devlet Matbaas1.

[16] Düstur, I. Tertip, C 3. (No Publishing Date).

[17] Eski Eserleri Koruma Encümeni 1939 Yılı Mesaî Raporu. (1940). İstanbul: Riza Koşkun Matbaası.

[18] Muhafaza-i Asar-ı Atika Encümen-i Daimisi Bir Senelik Mesaisine Dair Rapor. (1336).

[19] Takvim-i Vakayi, 1 Şubat 1284.

[20] Arseven, C. E. (1950). Eski Eserleri Koruma Encümeni. Sanat Ansiklopedisi, 1, 533-534.

[21] Baş, E. (2005). Târîh-i Osmânî Encümeni Kurucularından Efdaleddin (Tekiner) Beyin Hayatı, Eserleri ve Tarihçiliği Üzerine. Ankara Üniversitesi İlahiyat Fakültesi Dergisi, 46(2), 167-204.

[22] Çal, H. (1997). Osmanlı Devletinde Âsâr-1 Atîka Nizamnâmeleri. Vakıflar Dergisi(27), 391-400.

[23] Çobanoğlu, A. V., \& Özkan, E. (2002). Kemâleddin Bey, Mimar. Íslam Ansiklopedisi, 25, 230-231.

[24] Eyice, S. (1991). Arseven, Celâl Esat. İslam Ansiklopedisi, 3, 397-399. İstanbul: TDV.

[25] Eyice, S. (1995). Eldem, Halil Ethem. İslam Ansiklopedisi, 11, 18-21. İstanbul: TDV.

[26] Eyicil, A. (2006). Nâzım Bey. Íslam Ansiklopedisi, 32, 446-447. İstanbul: TDV.

[27] Kuruloğlu, F. (2010). Osmanlı Devleti'nde Müzecilik. Tarihi Okulu(VI), 45-61.

[28] Mumcu, A. (1969). Eski Eserler Hukuku ve Türkiye. A.Ü. Hukuk Fakültesi Dergisi, 34(26), 45-78.

[29] Özcan, A. (2011). Tekiner, Efdaleddin (1868-1957). İslam Ansiklopedisi, 40, 358-359. İstanbul: TDV.
[30] Sertoğlu, İ., \& Açık, T. (2013). Osmanlı Devleti'nde Modern Bir Okul Projesi: Müze-i Hümâyûn Mektebi. Gazi Akademik Baklş, 6(12), 157-172.

[31] Sürün, M. (2014). Mehmed Ziya Bey'in Ticaret Mekteb-i Âlîsi'nde İstanbul'daki Eski Anttlar Üzerine Verdiği Bir Konferans. ÇOMÜ Illahiyat Fakültesi Dergisi(4), 37-75.

[32] Şahin, G. (2007). Avrupalıların Osmanlı Ülkesindeki Eski Eserlerle İlgili İzlenimleri ve Osmanlı Müzeciliği. Tarih Araştırmaları Dergisi, 26(42), 101-125.

[33] Simşek, F., \& Dinç, G. (2009). XIX. Yüzyılda Osmanlı İmparatorluğunda Eski Eser Anlayışının Doğuşu ve $\mathrm{Bu}$ Alanda Uygulanan Politikalar. U.Ü. Fen-Edebiyat Fakültesi Sosyal Bilimler Dergisi, 10(2016), 101-127.

[34] Topal, Ş. (2013). Zilyedlik. İslam Ansiklopedisi, 44, 417-420. İstanbul: TDV.

[35] Ünlüoğlu, H., Alçakakar, Y. Z. (Prodüktörler), Ünlüoğlu, H., Şener, M., \& Öner, N. (Yönetenler). (1996a). Cumhuriyete Kanat Gerenler [Belgesel Filmi]. Temmuz 10, 2018 tarihinde

https://www.youtube.com/watch?v=AvQmUQ66j5E adresinden alınd

[36] Ünlüoğlu, H., Alçakakar, Y. Z. (Prodüktörler), Ünlüoğlu, H., Şener, M., \& Öner, N. (Yönetenler). (1996b). Cumhuriyete Kanat Gerenler [Belgesel]. Temmuz 10, 2018 tarihinde https://www.youtube.com/watch?v=ELzmaxclGRE\&t=122 $\mathrm{s}$ adresinden alınd 1

${ }^{\mathrm{i}}$ This study was presented orally at the International Congress of Culture and Science held on 3-5 May 2018 in Ankara.

ii According to Kuruloğlu, Edward Goold's appointment as the director of the Imperial Museum was on July 8, 1869. (Kuruloğlu, 2010, p. 48)

iii The pages with an odd number are empty in the manuscript which is electronically accessed in the Library Atatürk of İstanbul Metropolitan Municipality, and the pages of the manuscript are numbered in even numbers

iv Halil (Edhem Eldem) Bey was born in Istanbul on $24^{\text {th }}$ June of 1861 and was the son of the grand vizier Ibrahim Edhem Pasha and the brother of Osman Hamdi Bey and coinage expert Ismail Galib Bey. After studying in Berlin and Switzerland, Halil Bey returned to Istanbul after completing the philosophy doctorate (1885) and after working for the Deputy Minister of Porte Seraskerat Factory, he started to work in the translation branch of the Directorate of Military Officials. Halil Bey, who gave lessons in Darüssafakati'l-Islamiya (Ottoman Secondary School for Orphans of Islam) and Mekteb-i Mülkiye (Civil Service School) was appointed as assistant director of Imperial Museum of Historical Artifacts in 1892. In 1910, after the death of Osman Hamdi Bey, Halil Bey became the manager instead of him. Halil Bey, who was among the founders of the

Istanbul Association of the Historical Artifacts Lovers, helped the foundation of The Permanent Council for the Protection of Ancient Artifacts with his own efforts. (Eyice, 1995, pp. 18-19).

v Ismet Bey, who was elected as a member of The Permanent Council for the Protection of Ancient Artifacts when he worked as an Istanbul deputy, had worked as an deputy mayor of Istanbul and city prosecutor before being deputy (PMOA, BEO 4321/324055; DH.UMVM 139/11 ). Isme Bey (PMOA, DH.UMVM 139/11), who also served as a member of the Workhouse administrative council, was elected to membership of the Chamber of deputies substituted for Zöhrap Efendi (PMOA, DH.İ.UM 12-2/4-6), was rewarded a state commemoration by German Government (PMOA, I.DUIT 72/35) and died on 12 ${ }^{\text {th }}$ November of 1917 (PMOA, DH.I.U.M. 12-2 / 4-39).

vi Dr. Nazim Bey was one of the famous leaders of the Union and Progress Party. He was born in 1872 in Thessaloniki and Dr. Nazim studied at the Military Medical High School and then at the Medicine School. Then, he became a member of the Union of Ottoman Society, which would take the name of the Union and Progress Party later. He played a role with Ahmed Riza Bey in the publishing of the Newspaper Meşveret (Colsuntancy) in Paris, where he went in 1893. Since 1907, he 
had undertaken important duties in the organizing of the society in Turkey and abroad and opened new branches and played important roles in uniting the Ottoman Freedom Society in Thessaloniki, under the roof of the Union and Progress Party. Between $23^{\text {rd }}$ July of 1909 and $23^{\text {rd }}$ July of 1910, he served as a member of the Union and Progress Party, and served as a general member until 1918. He served as a Minister of Education in the cabinet of Talat Pasha on $21^{\text {st }}$ July 21 of 1918 and served this duty for three months. At the end of the World War I, he went to Berlin via Sevastopol. On $26^{\text {th }}$ August of 1926, he was executed by the Ankara Independence Court for the assassination of Izmir (Eyicil, 2006, pp. 446-447).

vii Architect Kemaleddin Bey was born in Istanbul in 1870. Kemaleddin Bey, who studied in Crete and Istanbul, received higher education in Ottoman School of Civil Engineering since 1887. In 1895, he was sent to Berlin where he studied for two years and worked for two years at the state architecture bureaus by a scholarship through a suggestion of his teacher Jasmund,. In 1889, he returned to Istanbul and in 1901 he was appointed to the Architecture of the Military Buildings in Ministry of War. Kemaleddin Bey, who served as the headmaster at the Ministry of Foundation (Awqaf) after the $31^{\text {st }}$ March Revolt, he was appointed to the newly established Construction and Repair Directorate (Cobanoğlu \& Özkan, 2002, p.230). While carrying out this duty, he was in charge of the construction of the fire places in Istanbul (PMOA, BEO 4155/311577) and the repairment of the sacred places in Medina and Jerusalem (PMOA, DH.ŞFR 61/274; İ..TAL 492/6) received Mejidi and the Ottoman commemoration on second rank (PMOA, İ.DUIT 68/120) due to his superior duties. Especially due to the success of the Masjid al-Aqsa in repair, he was elected as honorary member of the British Royal Academy of Architects. Architect Kemaleddin Bey lost his life on the grounds of a cerebral hemorrhage that he had in his house in Ankara on $13^{\text {th }}$ July of 1927 (Çobanoğlu \& Özkan, 2002, p.231)

viii Efdaleddin (Tekiner) Bey, was born in İstanbul Cerrahpaşa in 1868 His father was Ísmail Cevad Bey, the General Inspector of Private Treasury of the Ottoman Sultan. His mother was Emine Yegane Hanım, the daughter of poet Amedci Kenan Bey, a member of the Bayazidzade family of Maraș. He studied at Süleymaniye Primer School, Bayezid Kaptanpaşa Junior High School and the Civil Service High School (Baş, 2005, p 169). Efdaleddin Bey, who was appointed to the Caliphate of Amedi Divan-1 Humayun, gave lectures on Ottoman history in the Mülkiye and Sultani Schools (PMOA, MF.MKT 1109/14; MF.MKT 1091/41). Efdaleddin Bey, who was one of the founding members of the Council of the Ottoman History, made important contributions to the development of history in institutional sense. Efdaleddin Bey, who worked for both the Council of the Ottoman History and The Permanent Council for the Protection of Ancient Artifacts. He also worked for the Ottoman government as the Director of Prisons (PMOA, İ.DUIT 90/14) and worked for the Republic of Turkey and he was discharged in 1924 (PMRA, 30-11-1-0 / 4-12 -14). On $1^{\text {st }}$ June of 1928, Efdaleddin Bey who was given back to duty, got retired on $14^{\text {th }}$ October of 1928 (Baş, 2005, p.170). He was elected as the Turkish History Institution member in 1936 and Turkey Scientific Artifacts Protection Association permanent membership in 1940. While fulfilling this task, he struggled in order to get under historic preservation in Turkey (Özcan A., 2011, p. 359).

ix Mehmed Ziya Bey, son of the Director Tokat Foundation, Osman Vasfi Bey, was born in Istanbul in 1866. After studying at Hamidiye Primary School, Galatasaray Highschool and Fine Arts School he started to work as a civil servant at the Ministry of Finance. He started to work in Gümülcine, Edirne, Tekirdag, Aleppo, Konya, Bursa and Midilli High Schools and Istanbul Mahmudiye Ottoman Junior High School, Vefa, Numune-i Terakki and Mercan High Schools. After II. Constitutional Period, he worked in the Directorate of Statistics. He was a member of the Istanbul Lovers Association which was founded in 1911 and closed due to the World War I. In addition, he served in the commissions established for the rehabilitation of the Grand Education Assembly, Ministry of Education Delegation of Copyright and Translation, Islamic Foundations Assembly, Council of Ottoman History and foundation libraries (Sürün, 2014 p. 40). He wrote Istanbul and the Bosporus: The Remnants of Byzantine and Ottoman Civilization's Artifacts, Brief Information about Historical Artifacts in Istanbul, the Kariye Mosque and the Bereketzâde Fountain and he died on $27^{\text {th }}$ March of 1930 and were buried in Eyüp.

x Architect Asım (Kömürcüoğlu) Bey, who was born in 1879 in Skopje Kratova, was the son of Hayriye Hanım and Captain Eyüp Sabri Bey. Asim Bey, after he lost his parents, was raised by his uncle and his aunt He went first to the Monastery Military Junior High School, but since he could not find what he was looking for, he started to study the architecture of Vefa High School and then Fine Arts School. After finishing as the best student of this school in 1905, he began to work at Imperial Foundation as an architect (Unlüoğlu, Sener, \& Oner, Asım Kömürcüoğlu (Birinci Bölüm), 1996a). He worked in the restoration of the Green Tomb in Bursa
(Ünlüoğlu \& Alçakakar, 1996a; PMOA, İ.EV 45/32). He was sent to Berlin for his accomplishments and continued his education in architecture there. He started to work as the chief architect in the Municipality (PMOA, İ.DUIT 13/68) and also started to work as a teacher in Fine Arts School. Asim Bey, who returned to Berlin after World War I, also took part in the restoration of various artifacts and churches (Ünlüoğlu \& Alcakakar, 1996b). Asım Bey, who was involved in the reorganization of Beyazit Square, which suffered from the British bombardment, worked for a while as a contractor but he could not acquire success because of the economic depression. He became the first in the project competition for the construction of the Courthouse in Istanbul and took part in the creation of the city plans of many provinces and counties. He died in Ankara in 1957.

xi Celal Esad (Arseven) Bey was born in Istanbul in 1875. His father was Grand Vizier Ahmed Esad Pasha and his mother was Fatma Süzidil Hanım. Celal Esad Bey who lost his father in infancy was raised by Kazım Pasha, his uncle. After studying at Beşiktaş Taş Mektep and the Hamidiye School, he entered in the Galatasary Sultanate School for one year and then went to Besiktas Military High School and then to Civil Service School in 1889. Due to his interest in painting, he continued at the Fine Arts School. In 1891, Celal Esad Bey, who enrolled at the Military School due to his uncle's insists, did not give up his passion for painting while performing his duty as an officer. After the declaration of II Constitutional Period, he went to Paris and began to publish his magazine, "Kalem" with his friend Salah Cimcoz. He worked as the Chief of Galata Residence Registration Office in 1912; one year later he became Deputy Manager of Municipal Technical Works and Statistics and he left his work and was assigned to Kadıköy Municipality Directorate. Celal Esad Bey, who worked as a teacher at Fine Arts School in 1920, he served at Conservatory and the Director of Istanbul Chamber of Commerce Publication after 1923. Celal Esad Bey, who served as a deputy in 1942 and 1946, became a member of the Supreme Council of Antiquities and Artifacts in 1951 and died on 13th November of 1971. Celal Esad Arseven wrote and published many works on art, history and urbanism (Eyice, 1991, pp. 397-399).

xii The amount of 5000 cents required to be allocated for the expenditure of the Council for The Protection of Ancient Artifacts (August 2, 1917), which was established for the purpose of saving the historical artifacts from destruction and demolition, was demanded from the Ministry of Finance as the Ministry of Education did not have this budget. (PMOA, BEO 4479/335863)

xiii The Members of the Council in 1939 were as follows:

Aziz Ogan (President), Istanbul Archeology Museums General Manager; Arif Müfit Mansel (Member), Deputy Director of Istanbul Archaeological Museums;

Efdaleddin Tekiner (Member), Director of the University Library;

H. Fehmi Karatay (Member);

Abdülkadir Erdoğan (Member), Turkish and Islamic Artifacts Museum Director;

Nuri Ebusuudoğlu (Member), Former auditors of the Foundations Administration;

Süleyman Yörüken (Member), Director of the Museum of Internal Affairs;

Reşit Saffet Atabinen (Member), President of Turing Club;

Tahsin Öz (Member), Topkapı Palace Museum Manager;

İbrahim Bluğ (Member), Urban Planning Director;

Sedat Eldem (Member), Fine Arts Academy Professor;

Vahap Kocamemi (Member), former governor;

Avni Erbabacan (Clerk), Chief Clerk of the Museum. 